\title{
PENGUATAN FUNGSI EDUKASI PKK: PENDIDIKAN GENDER UNTUK MEMBANGUN KEHIDUPAN DEMOKRATIS
}

\author{
Oksiana Jatiningsih, Listyaningsih, dan Anik Andayani \\ Fakultas Ilmu Sosial Universitas Negeri Surabaya \\ email: oksianajatiningsih@yahoo.com
}

\begin{abstract}
Abstrak: Penelitian ini bertujuan untuk mengembangkan rancangan dan perangkat pendidikan gender yang dapat diterapkan melalui Pemberdayaan Kesejahteraan Keluarga (PKK). Kegiatan yang dilakukan pada penelitian tahap pertama adalah melakukan need asessment untuk memahami kondisi awal PKK di lokasi penelitian. Penelitian ini dilakukan di PKK Kecamatan Bandar Kedungmulyo Jombang. Berdasarkan Focus Group Discussion yang melibatkan Camat, penggerak PKK di tingkat kecamatan dan desa, terungkap bahwa PKK masih cenderung berfungsi menguatkan ideologi patriarkhi yang menempatkan perempuan pada fungsi-fungsi domestik. Dua kegiatan yang selalu direncanakan dalam program-programnya adalah arisan dan simpan pinjam, sementara kegiatan PKK yang terkait dengan fungsi edukasi PKK belum terencana dengan baik. Melalui penelitian pengembangan ini, fungsi edukasi PKK dirancang untuk dapat dikembangkan sebagai wahana pendidikan gender. Ibu-ibu yang melek gender ini pada gilirannya dapat menjadi agen sosialisasi gender yang egalitarian bagi anak-anaknya untuk mencapai keadilan gender menuju kehidupan yang demokratis.
\end{abstract}

\section{Kata Kunci: PKK, pendidikan gender, demokrasi}

\section{STRENGTHENING THE EDUCATIONAL FUNCTION OF THE FAMILY WELFARE EMPOWERMENT: GENDER EDUCATION TO DEVELOP A DEMOCRATIC LIFE}

\begin{abstract}
This study aimed to develop the design and the gender educational kits which could be applied through the Family Welfare Empowerment (PKK) activities. The activity undertaken in the first phase of the study was to conduct a needs assessment to understand the initial conditions of the PKK in the study setting. The study was conducted in PKK at Sub-district Bandar Kedungmulyo Jombang. Based on the focus group discussion involving the sub-district head, the PKK agents in the sub-district and the desa levels it was revealed that the PKK still served to strengthen the ideology of patriarchy by putting women in the domestic functions. Two activities which were always planned in the programs were arisan and simpan pinjam, while the PKK's activities related to its educational function had not been well planned. Through this research development, the educational functions of PKK were designed to be the place for mothers to understand gender. These mothers were expected to be the gender socialization agents for their own children to build gender equity for a democratic life.
\end{abstract}

Keywords: PKK, gender education, democracy

\section{PENDAHULUAN}

Peraturan Menteri Dalam Negeri No. 5 Tahun 2007 tentang Pedoman Penataan Lembaga Kemasyarakatan mengemukakan: "Gerakan PKK adalah Gerakan Nasional dalam pembangunan masyarakat yang tumbuh dari bawah yang pengelolaannya dari, oleh, dan untuk masyarakat menuju terwujudnya keluarga yang beriman dan bertaqwa kepada Tuhan Yang Maha Esa, ... kesetaraan dan keadilan gender, ...." Sayang sekali, faktanya, aktivitas PKK belum selalu berorientasi pada pengembangan keluarga yang ditandai oleh adanya kesetaraan dan keadilan gender. Organisasi PKK, bahkan banyak dikritisi karena keberadaannya yang justru menguatkan posisi dan fungsi perempuan di lingkup domestik dan mengekalkan dominasi ideologi patriarkhi dalam kehidupan. Aktivitasaktivitas PKK masih banyak diwarnai oleh penguatan fungsi perempuan sebagai ibu rumah tangga. Hal ini bukannya menguatkan pembentukan kesetaraan dan keadilan gender, tetapi justru menguatkan dan menjauhkan PKK dari keberhasilannya untuk membentuk keluarga 
yang didasarkan pada kesetaraan dan keadilan gender.

Dalam rangka pengembangan kehidupan yang demokratis, kehadiran PKK sebagai organisasi yang langsung bersentuhan dengan ibuibu dapat menjadikan PKK sebagai wadah untuk membongkar ideologi gender yang patriarkhi di masyarakat. Gerakan PKK sebagai organisasi yang ada di desa dan di kota berpeluang menjadi sarana pendidikan dan percepatan perwujudan kehidupan demokrasi di masyarakat. Anggota PKK adalah individu yang oleh masyarakat dikonstruksi sebagai pendidik pertama dan utama di rumah. Oleh karena itu, dalam konstruksi sosial ini, ibu adalah guru yang pertama dan utama bagi anak di keluarga. Seiring dengan itu, PKK dapat dimanfaatkan secara strategis dalam menyemaikan dan memperkuat akar kehidupan berkesetaraan gender dan demokratis. PKK dapat menjadi wadah pendidikan bagi ibu agar mereka dapat menjadi "guru" demokrasi yang siap menanamkan nilai-nilai kesetaraan gender yang pertama dan utama bagi anak-anaknya

Demokrasi adalah tatanan kehidupan yang ditandai oleh ciri-ciri liberty (kebebasan), egality (persamaan), dan fraternity (persaudaraan). Demokrasi adalah seperangkat gagasan dan prinsip tentang kebebasan dalam kebersamaan yang berlangsung dalam situasi persaudaraan. Setiap individu memiliki kebebasan dan berhak menggunakan kebebasannya. Meskipun demikian, kebebasan itu sama sekali tidak berarti dibolehkan melakukan penindasan terhadap pihak lain karena orang lain juga memiliki kebebasan yang harus dihargai. Oleh karena itu, karakter penting yang ada dalam kehidupan demokrasi adalah adanya pengakuan kesetaraan bagi semua perbedaan yang ada, termasuk perbedaan jenis kelamin. Laki-laki dan perempuan secara individual memiliki kebebasan yang sama. Oleh karena itu, keduanya harus saling menghargai.

Demokrasi tidak akan tercapai tanpa partisipasi seluruh individu. Ketchum (2004:88) mengatakan bahwa bekerjanya demokrasi berawal dari individu. Karena itu, penyiapan individu untuk dapat menjadi bagian dari pergerak- an demokrasi adalah hal yang penting dilakukan. Ibu adalah agen yang penting dalam penyiapan anak untuk menjadi individu yang demokratis. Tidak ada demokrasi tanpa kesetaraan dan keadilan gender. Dengan memperhatikan peran ibu sebagai guru dan agen sosialisasi gender di keluarga, PKK dapat mengambil peran penting dalam "membantu" dan menyiapkan ibu untuk dapat menjadi guru dan agen sosialisasi gender egalitarian bagi anak-anak dalam rangka membangun kehidupan yang demokratis. Dalam rangka itu, penting untuk dipertanyakan bagaimanakah strategi pelaksanaan pendidikan gender yang dapat dikembangkan melalui PKK?

Gender adalah konstruksi sosial tentang karakteristik dan peran laki-laki dan perempuan. Sebagai konstruksi sosial, gender bersifat relatif seiring dengan perkembangan masyarakat tersebut. Gender yang memuat sifat yang melekat pada kaum laki-laki maupun perempuan yang dikonstruksi secara sosial maupun kultural, mengekspresikan harapan sosial kepada laki-laki dan perempuan. Seiring dengan dinamika sosial, nilai-nilai gender pun dapat berubah pada ruang dan waktu yang berbeda.

Konstruksi gender tradisional (patriarkhi) meletakkan nilai keutamaan kepada laki-laki. Laki-laki berada pada posisi yang lebih tinggi daripada perempuan. Laki-laki adalah the first, perempuan adalah the second. Laki-laki berada pada posisi superordinat, perempuan di posisi subordinat. Dalam konstruksi gender tradisional, terjadi dikotomi stereotipe dan lingkup ativitas yang kuat. Masyarakat mengonstruksi perempuan sebagai sosok yang feminin, yaitu lembut, tidak asertif, cenderung mengalah, dan emosional, sedangkan laki-laki ditampilkan sebagai sosok yang besar, asertif, dominan, dan rasional (Susilastuti, 1993:29).

Perempuan yang feminin "dikodratkan" menjadi ibu rumah tangga yang bertugas mengurus kerumahtanggaan (lingkup domestik), sedangkan laki-laki yang maskulin adalah kepala keluarga yang bertugas mencari nafkah dan beraktivititas di lingkup publik. Dikotomi domestik-publik dan stereotipe maskulin-feminin yang kuat menimbulkan relasi gender yang tidak 
setara (bias gender), yang pada akhirnya menyebabkan terciptanya ketidakadilan. Dalam konstruksi gender yang patriarkhi, perbedaan gender berujung dengan peminggiran perempuan dalam berbagai bidang kehidupan.

Sebagai sistem relasi kekuasaan, gender menentukan semua kondisi kehidupan di lingkup publik maupun domestik (Maloutas, 2006: 2). Ketimpangan gender tidak merefleksikan kehidupan demokrasi yang ditandai oleh liberty (kebebasan), egality (persamaan), dan fraternity (persaudaraan). Demokrasi harus menghormati dan menggaransi kebebasan dan perbedaan antarindividu (Muloutas, 2006:11). Sesuai dengan pandangan tersebut, dalam demokrasi individuindividu anggota masyarakat memiliki kedudukan yang sama atau setara. Mereka memiliki kedaulatan atas dirinya sendiri atau kebebasan. Laki-laki dan perempuan berada dalam posisi yang setara gender. Laki-laki dan perempuan harus eksis secara bersama-sama secara setara di ruang publik. Oleh karena itu, konstruksi gender patriarkhi yang menempatkan laki-laki dan perempuan secara tidak setara tidak sesuai dengan nilai-nilai demokratis.

Ibu dikonstruksi sebagai penanggung jawab atas perawatan dan pendidikan anak-anak di rumah. Ibu (orang tua) dipercaya sebagai sumber sosialisasi gender yang paling signifikan dan sentral (Kretchmar, 2011:102; Grusec dan Davidov, 2007:285). Sosialisasi orang tua merupakan sumber perbedaan gender yang paling menentukan (Wharton, 2005:124). Peran gender ibu dapat dimodifikasi sebagai peran mendekonstruksi gender menuju nilai-nilai kehidupan yang egalitarian. Seiring dengan dinamika sosial dan tuntutan kehidupan demokratis, ibu dapat dipersiapkan menjadi "guru" gender dan demokrasi bagi anak-anak. Proses penyiapan ini dapat dilakukan melalui organisasi ibuibu, yaitu Pemberdayaan Kesejahteraan Keluarga (PKK). Melalui salah satu fungsi edukasinya, program-program PKK dapat diarahkan pada penyiapan ibu-ibu agar paham dan sadar, yang pada gilirannya diharapkan akan dapat mengedukasi anak-anak tentang perspektif gender.
Orang tua adalah model bagi anak. Kepadanya, anak akan berimitasi dan mengidentifikasikan diri. Melalui proses tersebut, anak mempelajari nilai gender sesuai dengan peran yang dijalankan orang tua mereka. Sesuai dengan teori belajar sosial (Stockard, 1999:217), stereotipe, perilaku, dan peran gender yang ditampilkan oleh orang tua membuat anak termotivasi untuk menampilkan stereotipe, perilaku, dan peran yang sama melalui proses imitasi dan identifikasi. Anak mempelajari gender dari apa yang dilakukan dan dikondisikan oleh orang tua melalui penguatan yang dilakukan dalam bentuk pemberian hadiah dan hukuman kepada anak. Hukuman dan hadiah tersebut menjadi pelajaran berharga bagi anak untuk mengulangi atau tidak mengulangi perilakunya.

Pada umumnya, orang tua berinteraksi secara berbeda kepada anak laki-laki dan perempuan. Hal tersebut menyebabkan anak lakilaki dan perempuan berkembang secara berbeda. Laki-laki berkembang menjadi maskulin dan perempuan menjadi feminin. Sementara itu, orang tua yang berinteraksi secara tidak berbeda kepada anak laki-laki dan perempuan lebih mengantarkan anak-anaknya menjadi pribadi yang memiliki dorongan berprestasi atau ketergantungan, hangat dalam berinteraksi, pembatasan (restrictiveness), dan praktik-praktik disiplin (Stockard 1999:217; Stockard dalam Kretchmar, 2011:103). Tenenbaum dan Leaper (Leaper dan Friedman, 2007:566) mengungkapkan bahwa terdapat asosiasi yang signifikan antara sikap gender orang tua dan sikap gender anak. Brannon (2005:145) mengemukakan bahwa ideologi gender orang tua mempengaruhi perkembangan gender anak. Oleh karena itu, ke depan diharapkan masyarakat berkembang ke arah yang demokratis. Pendidikan kepada anak sudah selayaknya diwarnai oleh nilai-nilai gender yang demokratis.

Dalam rangka menyiapkan ibu menjadi agen sosialisasi gender di rumah, pendidikan gender bagi ibu yang dirancang melalui kegiatan PKK ini dikembangkan berdasarkan prinsip belajar untuk orang dewasa (andragogi). Orang dewasa akan belajar dengan baik jika mereka berpartisipasi dalam proses belajar tanpa 
paksaan dan hal yang mereka pelajari berfungsi praktis baginya. Mereka terlibat dalam kegiatan tersebut karena kesadaran akan kebutuhannya. Karena itu, pembelajaran orang dewasa penting didasarkan pada refleksi kritis atas kondisi dan kebutuhan dirinya. Hal-hal yang bersifat teoretis dan tidak terkait langsung dengan tindakan praktis bukan menjadi prioritas. Salah satu pendekatan yang dapat dipilih dalam pembelajaran adalah pendekatan berpusat pada masalah (Srinivasan dalam Basleman dan Mappa, 2011: 23). Meskipun demikian, untuk membuka wawasan mereka tentang gender, diperlukan pula pengenalan terhadap beberapa konsep dasar gender.

Stimulus merupakan hal penting dalam proses belajar. Informasi gender, terutama yang memiliki nuansa berbeda dengan konstruksi gender yang telah dimiliki seseorang dapat menjadi alternatif berpikir dan pilihan bagi subjek yang sudah dewasa sebagaimana dikemukakan oleh Eccles (1995:187) dan Stangor dan Ruble (Baron dan Byrne, 1991:122). Banyak faktor yang mempengaruhi proses pendekonstruksian gender pada individu dewasa. Selain proses sosialisasi sebelumnya, proses belajar aktif, kemampuan berpikir, dan analisis kritis memiliki peran yang besar dalam proses tersebut. Berkaitan dengan itu, pengalaman pribadi dan pengamatan sosial, serta pengetahuan seseorang tentang gender dan peran gender menjadi sumber pelajaran gender, yang secara bersama-sama dapat menumbuhkan perasaan dan kesadaran terhadap ketidakadilan gender, terutama dialami perempuan.

Mendekonstruksi nilai pada orang dewasa tidaklah mudah, tetapi betapapun informasi gender yang non-tradisional tidak mudah diingat oleh orang tua, sebagaimana yang terjadi pada anak-anak yang skema gendernya yang belum mantap. Namun demikian, informasi itu tetap akan berguna untuk memberikan alternatif pikiran dan pilihan kepada mereka untuk melihat alternatif aktivitas yang diwarnai oleh stereotipe gender yang non-tradisional dan kemudian mendekonstruksi konsep gendernya, sebagaimana diungkapkan oleh Eccles (1995:187) dan Stangor dan Ruble (Baron dan Byrne, 1991:
122). Pengalaman, kebutuhan, dan kesempatan baru yang berlangsung sepanjang kehidupan manusia merupakan faktor-faktor yang dapat memotivasi individu dewasa untuk "menilai" ulang konstruksi gendernya. Sesuai dengan pandangan Freire bahwa pendidikan harus memerdekakan, pendidikan harus menjadi praktik yang memungkinkan peserta belajar menemukan dirinya sendiri dan memiliki kesadaran (konsientasi) untuk melakukan perlawanan terhadap domestikasi yang dilakukan.

\section{METODE}

Penelitian ini merupakan jenis penelitian pengembangan karena penelitian ini bermaksud mengembangkan aktivitas dan perangkat pendidikan gender yang diaplikasikan melalui kegiatan PKK. Pengembangan model pendidikan dilakukan dengan menggunakan model 4D yang meliputi define, design, develop, dan dissemination (Thiagarajan, Simmel \& Simmel, 1985)

Setting kegiatan penelitian ini adalah PKK. Subjek dalam penelitian ini adalah delapan orang tim penggerak PKK di Kecamatan Bandar Kedungmulyo, lima orang penggerak PKK di desa, dan tiga orang ibu-ibu anggota PKK. Subjek dipilih secara purposive berdasarkan pertimbangan kesediaan mereka dijadikan subjek penelitian dan keterlibatannya dalam kegiatan PKK.

Aktivitas yang dilakukan dalam penelitian tahun pertama ini adalah need assesment yang dijadikan dasar untuk menentukan model aktivitas dan tema-tema esensial yang dapat dikembangkan dalam produk penelitian yang dihasilkan. Data ini selanjutnya dianalisis secara kualitatif. Proses analisis kualitatif ini terdiri atas tiga sub proses kegiatan, yaitu penyajian data, reduksi data, dan verifikasi (Miles dan Huberman; 1992:20).

\section{HASIL DAN PEMBAHASAN \\ Hasil}

Berdasarkan FGD yang dilaksanakan dapat dikemukakan bahwa kegiatan rutin PKK adalah arisan dan simpan pinjam. Mereka mengungkapkan bahwa PKK bisa dimanfaatkan sebagai ajang pertemuan dan komunikasi an- 
taribu-ibu. Sesekali kegiatan rutin yang dilakukan diselipi dengan kegiatan penyuluhan atau penyampaian informasi yang tampaknya bersifat insidental.

PKK Kecamatan Bandar Kedungmulyo selama ini belum pernah mengagendakan secara terprogram kegiatan edukasi kepada anggotanya. Kegiatan pendidikan yang dilakukan selama ini masih sebatas pada penyuluhan atau penyampaian informasi. Kegiatan semacam ini dilakukan ketika misalnya, tim penggerak PKK tingkat kabupaten menyampaikan informasi atau pengetahuan kepada mereka. Pada saat seperti itu, mereka kemudian merancang untuk menyampaikan atau meneruskan informasi itu kepada tim penggerak PKK di tingkat desa melalui pertemuan rutin bulanan yang diselenggarakan. Kegiatan semacam ini tidak disertai oleh pemantauan apakah informasi itu kemudian juga disampaikan kepada anggota PKK di tingkat desa, bagaimanakah proses penyampaiannya berlangsung, serta bagaimana hasilnya.

Catatan penting lain yang bisa diungkapkan terkait dengan kegiatan ini adalah tidak adanya persiapan tentang kecukupan pengetahuan dari para penyampai informasi di tingkat desa. Informasi yang pernah diperoleh dari kabupaten dan kemudian dilanjutkan dengan kegiatan yang sama, misalnya terkait dengan informasi gender dan kesehatan, atau informasi politik yang biasanya dilaksanakan ketika mendekati momen-momen penting seperti pemilihan umum atau pemilihan kepala daerah. Bentuk kegiatan penyuluhan yang lain biasanya disampaikan oleh pihak luar, misalnya dari dinas kesehatan, atau aktivitas pemberantasan buta aksara fungsional. PKK hanya menjadi semacam wadah berkumpulnya ibu-ibu yang menjadi sasaran kegiatan tersebut.

Menyusul kebijakan pemerataan kesempatan memperoleh pendidikan di tingkat anak usia dini, sesuai dengan kebijakan tim penggerak PKK di tingkat provinsi, di setiap desa dikembangkan pendidikan anak usia dini. Sekolah PAUD ini dikelola oleh PKK di tingkat desa dengan guru-guru yang antara lain direkrut dari ibu-ibu yang bersedia dididik untuk tujuan tersebut. Guru-guru ini disebut dengan istilah bun- da PAUD. Peran tim penggerak PKK dalam kaitannya dengan kegiatan ini adalah menyediakan fasilitas yang diperlukan. Upaya-upaya khusus terkait dengan pembinaan guru sepenuhnya mengikuti kebijakan dari tim penggerak PKK kabupaten atau instansi yang terkait dengan itu, misalnya dinas kesehatan atau puskesmas.

Kegiatan edukasi lain yang telah dilakukan misalnya melalui kegiatan pengajian ibuibu. Melalui kegiatan ini, dilakukan proses pendidikan yang berkaitan dengan kegiatan pembinaan keimanan dan ketakwaan.

Berdasarkan FGD yang dilakukan, tim penggerak PKK masih cenderung bertindak sebagai pelaksana kegiatan, belum memosisikan diri sebagai perancang kegiatan. Kegiatan pendidikan untuk tujuan tertentu yang sengaja dirancang oleh PKK belum pernah dilaksanakan. Oleh karena itu, ketika tim peneliti menawarkan alternatif pemikiran untuk menjadikan PKK lebih fungsional lagi dalam mengedukasi anggotanya, tim penggerak PKK antusias menyambutnya.

Sesuai dengan tema yang diangkat dalam penelitian ini, dalam FGD dicoba ditawarkan topik demokrasi dan pendidikan gender. Demokrasi penting dan harus diperjuangkan. Mereka sependapat bahwa demokrasi adalah bagian penting dalam kehidupan bernegara, sehingga penting dijadikan topik pendidikan. Hampir seluruh ibu penggerak PKK yang hadir menyatakan bahwa pendidikan formal yang lebih berperan dalam menyiapkan anak menuju kehidupan demokrasi. Sekolah dipandang sebagai institusi yang paling bertanggung jawab dalam mengedukasi generasi muda terkait dengan kehidupan demokrasi. Hampir terabaikan bahwa demokrasi bukanlah sekedar aturan kehidupan yang timbul begitu saja. Demokrasi dibangun oleh individu-individu yang memiliki komitmen terhadap kehidupan itu. Karena itu, demokrasi memerlukan individu-individu yang berkarakter demokratis. Karakter demokratis ini ditumbuhkan dan dikembangkan tidak hanya oleh sekolah, tetapi diletakkan dasar-dasarnya oleh ibu yang dikonstruksi secara sosial sebagai pendidik pertama dan utama bagi anak-anak. 
Ketika "pencerahan" tentang peran keluarga dalam mendidik karakter demokratis dan karakter anak laki-laki dan perempuan dikemukakan, mereka kemudian bereaksi secara positif bahwa karakter anak laki-laki berbeda dengan anak perempuan. "Mendidik anak perempuan untuk disiplin terhadap dirinya sendiri lebih mudah daripada mendidik anak laki-laki," demikian diungkapkan oleh seorang ibu yang hadir dalam kegiatan FGD. Pernyataan ini kemudian didukung oleh banyak ibu yang lain.

Pembicaraan menjadi hangat karena "topik anak" yang sedang dibahas. Topik ini adalah topik yang begitu dekat dengan kehidupan ibu-ibu sebagai agen yang dikonstruksi masyarakat sebagai pelaku pendidikan yang pertama dan utama.

"Menurut saya, anak harus diberi kesibukan yang positif agar tidak terbawa arus. Saya menyuruh anak saya laki-laki untuk ikut sepak bola.... kalau perempuan, ya nggaklah. Mereka lebih bisa mengendalikan diri, tetapi perlu juga sibuk dengan kegiatan. Tapi tidak main bola tentu. Tak akan saya izinkan. Saya menyuruh anak saya ikut fashion show. Anaknya cantik, tinggi dan putih, dan kegiatan itu cocok dengan sifat perempuan."

"Mengapa anak laki-laki dan perempuan berbeda ya?" demikian dilontarkan oleh salah satu tim peneliti. Respon yang diungkapkan salah seorang ibu demikian, "Ya mengapa ya? Apa memang begitu dari sananya ya?" Ibu-ibu yang lain tidak menjawab, namun malah menguatkan dengan contoh bahwa anak laki-lakinya memang berbeda dengan anak perempuannya. "Kalau bangun tidur itu tidak mau menata tempat tidurnya. Meletakkan barang sembarangan dan main terus kerjaannya... beda dengan adiknya yang perempuan, ngerti membantu orang tua."

Persoalan rendahnya kualitas dan kuantitas perempuan yang terlibat pada proses berdemokrasi dan dalam aktivitas publik yang lain hampir tidak menjadi cermatan mereka sampai saat peneliti mencoba mengungkapkan persoalan itu. Mereka tidak cukup resah dengan sedikitnya jumlah perempuan yang menjadi wakil rakyat atau pimpinan instansi. Dunia politik tidak terlalu mengusik kecemasan mereka. Politik dipandang lebih cocok untuk laki-laki. Perempuan agak sulit jika terjun ke dunia politik. "ya, pulang malam-malam dan pergi-pergi terus tidak mungkin dilakukan oleh ibu," kata seorang ibu.

Mereka bersepakat jika perempuan wajib sekolah seperti halnya anak laki-laki. Namun, pentingnya mereka sekolah berbeda pada lakilaki dan perempuan. Laki-laki dipahami sebagai individu yang wajib bekerja, tetapi saat ini perempuan sebaiknya memang bekerja. Mereka mengatakan "Perempuan yang bekerja bisa membantu memperbaiki ekonomi keluarga." Selain itu, jika mau bertindak yang terkait dengan uang, mereka merasa lebih leluasa, karena tidak sungkan dengan suaminya. "Tugas istri adalah membantu dan mendampingi suami." Artinya, apapun yang dilakukan istri tidak boleh melupakan bahwa perempuan harus mengurus anak-anak dan suaminya.

Demokrasi dipahami ibu-ibu sebagai proses yang berkaitan dengan kehidupan bernegara dan berpolitik. Oleh karena itu, demokrasi itu hampir selalu dikaitkan dengan kegiatan pemilihan pimpinan, seperti pemilihan umum, pemilihan presiden, atau pemilihan kepala daerah. Partisipasi warga masyarakat terhadap persoalan-persoalan publik dan upaya alternatifnya belum menjadi bagian yang terperhatikan sebagai bagian dari demokrasi. Menurut mereka, setiap orang berhak memberikan pilihannya sesuai dengan keyakinannya. Istri tidak harus menurut suami untuk itu. Pertimbangan yang rasional atas pilihannya merupakan bagian yang penting untuk dimiliki semua orang, baik laki-laki maupun perempuan. Hal ini disebut sebagai kewajiban warga negara.

Informasi tentang gender telah diperoleh beberapa pengurus dari tim penggerak kabupaten PKK, namun informasi itu belum cukup berarti membuat mereka memahami konsep gender dengan baik. Padahal, untuk melaksanakan fungsi kegiatan yang dirancang ini, pemahaman atas konsep-konsep gender menjadi bagian yang penting. Bahkan, tidak hanya itu, kepekaan dan kesadaran gender perlu dimiliki oleh tim penggerak PKK dalam rangka me- 
nyosialisasikan nilai-nilai gender dalam kegiatan pendidikan ini. Hal tersebut mengimplikasikan pentingnya pencerahan tentang konsep gender sehingga mereka memiliki kesensitifan dan kesadaran gender. Mereka perlu mendapatkan informasi yang lebih dalam tentang gender.

Ibu-ibu bersepakat bahwa perempuan harus dapat bekerjasama dengan laki-laki, sebaliknya laki-laki juga harus bisa bekerjasama dengan perempuan. "Pada umumnya, memang laki-laki lebih maju daripada perempuan, sehingga perempuan memang harus banyak belajar untuk itu," demikian yang dikatakan oleh seorang ibu. "Kalau perempuannya pintar, maka laki-laki pun suka bekerjasama dengan dia," tambahnya. "Perempuan suka lama dalam mengambil keputusan. Perempuan kurang cermat dalam berpikir." "Perempuan kadang-kadang emosional dan suka gupuhan ketika menghadapi masalah."

Demikian beberapa pandangan yang dilontarkan tentang kelemahan perempuan yang mungkin dapat menghambatnya ketika bekerja sama dengan laki-laki. "Untuk dapat menjadi mitra, laki-laki dan perempuan memang harus sama. Kalau sama-sama pintar ya senang bisa kerjasama, kalau yang satu tidak pintar, wah.... jadi nggandol saja. Tidak bisa kerjasama." Berdasarkan data tersebut, dapat dikemukakan bahwa kualitas individu, misalnya kepandaian dan kemampuan mengambil keputusan adalah halhal yang penting untuk dimiliki, terutama oleh perempuan agar dapat bekerjasama dengan lakilaki.

Dalam rangka pembebasan belenggu dan penegakan demokrasi, diharapkan beberapa karakter dimiliki oleh anak laki-laki atau perempuan. Tiga karakter yang diharapkan dimiliki oleh baik anak laki-laki maupun perempuan adalah tanggung jawab, disiplin, dan mandiri. Selain itu, dalam rangka menegakkan kehidupan demokrasi, menurut mereka penting juga bersikap saling menghargai, toleransi, percaya diri, rasional, kritis, dan bersifat terbuka. Karakter-karakter ini yang kemudian akan dikembangkan lebih lanjut dalam paket materi pendidikan gender.

\section{Pembahasan}

Berdasarkan FGD yang dilakukan dapat dikemukakan bahwa ibu-ibu tim penggerak PKK belum sepenuhnya memahami konsep gender dan demokrasi. Beberapa konsep masih dipahami secara salah. Selain persoalan konseptual, bias gender juga masih ditemukan dalam pemikiran mereka. Dalam beberapa hal, mereka mengemukakan bahwa perempuan dan laki-laki adalah mitra sejajar dan mereka berharap bahwa perempuan bisa begitu. Namun faktanya, dalam beberapa hal mereka masih berpikir dan berinteraksi secara bias dengan anaknya.

Oleh karena itu, aktivitas dan perangkat pendidikan gender untuk tujuan "pencerahan" pengetahuan gender dan demokrasi diperlukan. Pencerahan ini diharapkan dapat membuka "kesadaran palsu" yang hidup dalam konstruksi gender yang membuat mereka begitu saja melakukan praktik-praktik gender yang bertentangan dengan pemikirannya. Mereka lebih memposisikan diri menjadi "me" (objek) daripada "I" (subjek). Menurut Mead yang berkaitan dengan interaksionisme simbolik, the self adalah bentukan dari proses sosialisasi yang panjang yang mengekspresikan begitu kuatnya nilai-nilai patriarkhi dalam diri ibu-ibu.

Konstruksi gender yang bias yang masih cukup kuat berlaku pada ibu-ibu tim penggerak PKK ini merefleksikan kuatnya sosialisasi. Hal ini merefleksikan bahwa pengalaman sosialisasi perlu ditata sedemikian rupa sehingga relevan dengan nilai-nilai yang diharapkan dimiliki oleh anak. Ikatan normatif gender tentang bagaimana seharusnya seseorang "berperan" dan "menjadi" begitu kuat tertanam pada diri mereka akibat proses interaksi dan sosialisasi panjang yang dialami sebelumnya.

Mengubah sistem nilai dalam diri seseorang tidaklah mudah, apalagi pada orang dewasa. Perubahan konstruksi nilai pada orang dewasa dapat dilakukan melalui pemberian stimulus secara praktis sehingga pada dirinya timbul perasaan tidak nyaman, tidak adil, dan kebutuhan untuk berubah. Mereka perlu pengalaman praktis tersendiri yang membuat mereka menjadi dapat berpikir kritis (alternatif) 
berdasarkan "kekecewaan" dan "penderitaan" yang ditemukan dalam pengalaman atau pengamatan terhadap fenomena sosial.

Sebagaimana dikemukakan oleh Ruble (Baron dan Byrne, 1991:122), bahwa individu "harus" dibuat menyadari adanya ketimpangan gender sehingga ia merasa tidak puas terhadap suatu keadaan dan merasa perlu untuk menghadirkan dalam dirinya nilai-nilai gender yang non-tradisional. Bagi orang dewasa, untuk bisa keluar dari belenggu "dominasi patriarkhi" yang dapat menghambat kehidupan demokratis, diperlukan "perjuangan rasional" untuk melawan kekuatan nilai dalam dirinya, sehingga mereka merasa perlu mengubah dan keluar dari sistem nilainya yang lama. Sesuai dengan teori kognitif/social development, informasi-informasi yang dirancang dalam materi dan kegiatan pendidikan gender ini adalah informasi praktis dan realistis yang membuat subjek menyadari dampak ideologi gender patriarkhi.

"Kekuatan" untuk melawan hegemoni nilai gender tradisional itu akan muncul seiring dengan kemampuan berpikir kritis seseorang sehingga ia mampu membaca adanya ketidakadilan pada sekelompok orang tertentu dan dirinya. Untuk tujuan ini, kepekaan dan kesadaran gender perlu ditumbuhkan kepada ibu-ibu.

Belajar bagi orang dewasa akan terjadi karena apa yang dipelajarinya bermakna bagi dirinya. Sesuai dengan pendapat Ausubel (Basleman dan Mappa, 2011:91), pembelajaran bermakna akan didapat jika materi secara potensial bermakna bagi peserta belajar. Tidak seorang pun yang tidak memiliki harapan baik atas kehidupan anaknya. Hal ini bisa membuka kemampuan belajar orang tua sehingga ia akan berjuang keras menjadikan anaknya mendapatkan yang terbaik bagi kehidupannya pada masa yang akan datang. Pendidikan orang dewasa menjadi bermakna jika materi yang dipelajari dapat menimbulkan kesadaran pada peserta belajar. Kesadaran yang dimaksud dapat menumbuhkan kekuatan untuk melawan dominasi, salah satunya dominasi gender. Pedagogis kritis dibutuhkan dalam kehidupan demokratis (Tilaar, 2011:17).
Dalam rangka mengembangkan kehidupan yang demokratis dan penyiapan anak menuju kehidupan itu, penelitian ini dirancang agar dapat memberikan pencerahan terkait wawasan gender dan demokrasi. Demokrasi adalah kehidupan yang ditandai oleh kebebasan dan kesamaan. Oleh karena itu, tema-tema karakter gender yang berorientasi pada demokrasi yang dikembangkan dalam produk ini adalah tanggung jawab, disiplin, mandiri, rasional/logis, saling menghargai, toleransi, dan kesetaraan. Dikotomi karakter feminin dan maskulin yang menyebabkan terjadinya subordinasi satu pihak terhadap yang lain tidak menjadi orientasi pendidikan gender yang dikembangkan. Baik lakilaki atau pun perempuan harus didorong untuk mendapatkan kesempatan yang sama untuk merealisasikan diri (Maloutas, 2006:16).

Selain itu aktivitas penelitian ini, ibu-ibu PKK dalam jangka panjang diharapkan dapat mengembangkan kesensitifan dan kesadaran gender yang diperlukan dalam sosialisasi gender yang egalitarian. Dalam rangka hal tersebut, aktivitas penelitian ini dirancang untuk bisa membekali ibu-ibu dan tim penggerak PKK agar memiliki kecakapan tersebut. Melalui kecakapan ini, diharapkan ibu dapat mengembangkan interaksi berperspektif gender di lingkup keluarga mereka.

Ibu-ibu memiliki multi peran yang cukup banyak menyita waktunya. Berpangkal pada fakta itu, maka aktivitas pendidikan gender yang dirancang untuk ibu-ibu PKK ini tidak boleh menyita waktu mereka lebih banyak lagi. Aktivitas pendidikan gender dirancang menjadi bagian dari kegiatan pertemuan rutin PKK. Ada beberapa catatan penting terkait dengan pelaksanaan kegiatan ini. Pertama, kelak pelaksana (motor) kegiatan ini adalah para ibu penggerak PKK itu sendiri. Oleh karena itu, mereka perlu dipersiapkan agar dapat bertindak menjadi "trainer" atau sumber informasi. Kedua, kegiatan ini dikembangkan dengan memperhatikan prinsip pembelajaran andragogi. Oleh karena itu, aktivitas penyiapan tenaga trainer yang berpengetahuan, sensitif, dan sadar gender dan demokrasi diperlukan. Aktivitas TOT DOUI yaitu Training of Ttrainer dari, oleh, dan untuk ibu 
dipilih sebagai aktivitas pertama untuk menyiapkan ibu-ibu penggerak PKK yang kelak akan melakukan aktivitas edukasi gender kepada ibu-ibu anggota PKK. Aktivitas training ini dilakukan secara khusus, namun aktivitas pendidikan gender untuk ibu dilakukan sebagai bagian kegiatan edukasi pada pertemuan rutin PKK.

Pelaksanaan program seperti ini selain berfungsi untuk lebih memberdayakan PKK dalam fungsi dan perannya di bidang pendidikan, kegiatannya juga merefleksikan peluang belajar seumur hidup. Program pendidikan gender menuju demokrasi ini diterapkan secara terprogram dalam kegiatan rutin PKK di tingkat desa. Untuk kepentingan itu, upaya penyiapan tenaga "trainer" yang akan menjadi motor penggerak kegiatan pendidikan gender perlu dilaksanakan melalui kegiatan pelatihan yang khusus dirancang untuk itu yang dalam penelitian ini disebut TOT DUOI. Melalui aktivitas pendidikan gender ini, PKK yang selama ini lebih berfungsi menguatkan ideologi gender patriarkhi dirancang sebagai sarana dan wadah untuk menanamkan ideologi gender egalitarian dalam rangka mewujudkan kehidupan demokrasi.

\section{PENUTUP}

Berdasarkan kegiatan need assesment yang dilakukan dapat disimpulkan beberapa hal sebagai berikut. (1) Penguatan wawasan gender dan demokrasi kepada para tim penggerak PKK kecamatan masih diperlukan sebagai awal pelaksanaan dan keberhasilan program ini. Untuk keperluan tersebut, dirancang kegiatan TOT DOUI. Peserta TOT inilah yang selanjutnya akan melakukan program pendidikan gender untuk ibu-ibu pada kegiatan pertemuan rutin PKK. (2) Sesuai dengan prinsip liberty, egality, dan fraternity, tema-tema karakter gender yang berperspektif demokratis yang dikembangkan dalam penelitian ini adalah tanggung jawab, disiplin, mandiri, rasional/logis, saling menghargai, toleransi, dan kesetaraan.

\section{UCAPAN TERIMA KASIH}

Ucapan terima kasih disampaikan kepada Direktorat Penelitian dan Pengembangan, Dirjen Dikti, yang telah mendanai penelitian ini melalui program Penelitian Strategi Nasional

\section{DAFTAR PUSTAKA}

Baron, Reuben M. dan William G. Graziano. 1995. Sosial Psychology. Chicago: Holt, Rinehart and Winston, Inc.

Basleman, Anisah dan Sayamsu Mappa. 2011. Teori Belajar Orang Dewasa. Bandung: Remaja Rosdakarya.

Brannon, Linda. 2005. Gender Psychologycal Perspective. Cetakan Keempat. Boston: Pearson.

Eccles, Jacquelynne Parsons, 1995. "GenderRole Socialization." Baron, Reuben M. dan Graziano, William G., Social Psychology. Chicago: Holt, Rinehart and Winston, Inc.

Grusec, Joan E. dan Maayan Davidov. 2007. "Socialization in the Family. The Roles and Parents." dalam Handbook of Socialization. Theory and Research. Joan B. Grusec dan Paul D. Hastings (editors). Halaman 284-308. New York: The Guilford Press.

Ketchum, Richard M. 2004. What is Democracy? Terjemahan oleh Mukhtasar. "Pengantar Demorasi”. Yogyakarta: Niagara.

Kretchmar, Jennifer. 2011. "Gender Socialization”. dalam Sociology Reference Guide. The Process of Socialization. The Saleem Press (Editors). Halaman 97-108. California: Salem Press.

Leaper, Campbell dan Carly Kay Friedman, 2007. "The Socialization of Gender" dalam Handbook of Socialization. Theory and Research. Joan B. Grusec dan Paul 
D. Hastings (Editors). Halaman 561-587. New York: The Guilford Press.

Maloutas, Maro Pantelidou. 2006. The Gender of Democracy. Citizenship and Gendered Subjectivity. New York: Routledge.

Miles, Matthew B. dan A. Michael Huberman. 1992. Qualitative Data Analysis. Terjemahan oleh: Tjetjep Rohendi Rohidi. Jakarta: UI Press.

Peraturan Menteri Dalam Negeri No. 5 Tahun 2007 tentang Pedoman Penataan Lembaga Kemasyarakatan.

Stockard, Jean. 2006. "Gender Socialization." dalam Handbook of Sociology of Gender. Editor: Janet Salman Chafetz. Halaman 215-228. Houston: Springer.
Susilastuti, D.H. 1993. "Jender Ditinjau dari Perspektif Sosiologi." dalam Fauzie Ridjal, Lusi Margiyani, dan Agus Fahri Husein (eds.) Dinamika Gerakan Perempuan di Indonesia. (hlm. 29-36) Yogyakarta: Tiara Wacana.

Thiagarajan, Simmel \& Simmel. 1985. Development Research Model in Education. Boston: Allyn \& Bacon.

Tilaar, H.A.R., Jimmy Ph. Paat, dan Lody Paat. 2011. Pedagogik Kritis Perkembangan, Substansi, dan Perkembangannya di Indonesia. Jakarta: Rineka Cipta.

Wharton, Amy S. 2005. The Sociology of Gender: An Introduction to Theory and Research. Oxford: Blackwell Publishing. 